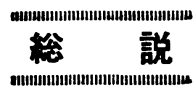

\title{
鉄鋼の酸洗機構 と鉄酸化物溶解の電気化学
}

\section{1. 緒言}

熱間圧延処理によって鋼板を製造するさい，その表面 に酸化物スケール（いわゆる mill scale）が生成するが, これは最終的に種々の表面仕上げ（金属被覆，有機質塗 装など）を施すため, 酸洗処理 (acid pickling) によっ て除去しなければならない。酸洗は通常インヒビターを 加えた硫酸，塩酸などの溶液中に試料を浸漬するという 一見きわめて簡単な操作であり, 従来酸濃度, 温度, イ ンヒビターの種類などの操業条件は単なる経験と現場的 な配虑のみで処理されてきた。しかし最近諸種の金属表 面処理技術が急速に発展しつつある事情もあり，この問 題を基本的に検討すべき時期がきたのではないかと考元 る。その第一着手としては, 酸洗機構を解明するため, スケールの微細構造ならびにスケールを構成する各種酸 化物の溶解挙動に関する知見を集積し整理してみる必要 がある。前者に関しては熱圧延および冷却条件など試料 の温度履歴の影響が重要であるし，後者については地鉄 の存在による効果, 処理液の性質との関係が重要である う。酸洗挙動の特性を理解し，これを自由にコントロー ルしうるためには，上記の二つの問題に関し確実な知識 を得, かつそれら相互の関連を明確に把握することが必 要であって，これは今後各分野の研究者・技術者の一層 の協力を必要とする。

本総説においては，これまで諸研究者によって得られ たスケールの構造に関する知識の概要を述べるととも に, Engell 一派の研究結果を中心とし酸洗機構の電 気 化学的見方について解説を加えた。

\section{2. スケールの構造と性筫}

(a) スケールの生成

鉄鋼表面における酸化物スケールの生長速度は，温度 および酸素分圧の関数であり，これらの一定条件の下で は概略的に放物線法則 $x^{2}=k t$ が成立する。ここで $x$ は スケールの重量増加, $t$ は時間, $k$ は速度定数である。 温度による $k$ 值の変化はかなり著しく, $500^{\circ} \sim 1,100^{\circ} \mathrm{C}$ の範囲で見かけの活性化ェネルギーが $33 \mathrm{kcal}$ という大 きな値を示す。空気開放の条件下で生成するスケールの 厚さは温度および反応時間の関数としてきまるわけであ るが，鋼板スケールは压延時主として $950^{\circ} \sim 600^{\circ} \mathrm{C}$ の 範囲において生じたもので通常 $5 \sim 10 \mu$ の厚さを有す る。これは比較的短時間の酸化に相当する。

* 北海道大学工学部工業分析化学数室 (札熀市北 12 条西 8 丁目)

\author{
永 山政 一* 川 村 静 夫*
}

鉄鋼を $570^{\circ} \mathrm{C}$ 以上で酸化し急冷後にスケールの組織 を調べると 3 種類の酸化物からなりたっている1)。すな わち内側の地鉄と接するところに wustite $\left(\mathrm{Fe}_{1-y} \mathrm{O}\right)$, 中 間に magnetite $\left(\mathrm{Fe}_{3} \mathrm{O}_{4}\right)$, 外側には hematite $\left(\alpha-\mathrm{Fe}_{2}\right.$. $\mathrm{O}_{3}$ ) の各層が存在する。ウスタイトは常に $\mathrm{Fe}$ 不足型の 欠陷構造を有し， $\mathrm{Fe}_{1-y} \mathrm{O}$ のように表わす。y は通常鉄 /酸化物界面からの距離とともに増大し $0.05 \sim 0.16$ の 範囲で種々の值をとる (図 1) 2)。本文中においては, 以 下簡単のため $\mathrm{FeO}$ という記号を用いるが，これはつね に欠阷構造のウスタイトを意味する。

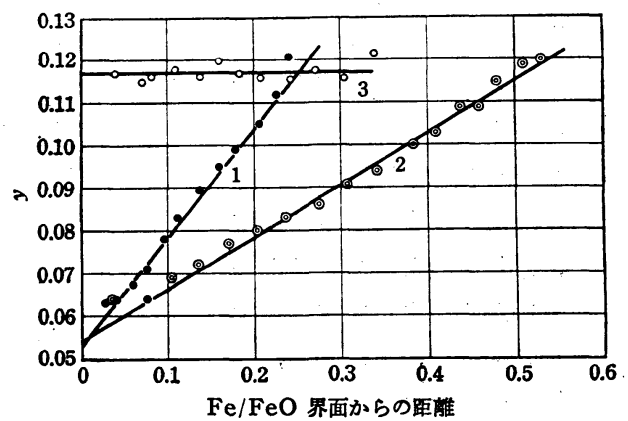

图 $1 \mathrm{Fe}_{1-y} \mathrm{O}$ の $y$ 值の $\mathrm{Fe}$ 面からの距離による変 化 (Engell) (烧成温度 $900^{\circ} \mathrm{C}$ )

1: 地铁との密着性良好の場合 (燒成時間 60 分) 2: 地鉃との密着性良好の掦合 (烧成時間 202 分) 3: 地鉄との密着性不良の場合 (焼成時間 230 分)

Birchenall3) および Paidassi4) によれば， $625^{\circ} \mathrm{C}$ 以 上においてこれら 3 つの層の相対的な量はほぼ一定であ り, 概略 $\mathrm{FeO}(95 \%), \mathrm{Fe}_{3} \mathrm{O}_{4}(4 \%), \mathrm{Fe}_{2} \mathrm{O}_{3}(1 \%)$ 程度で あるが，一般に温度が低くなるにつれて $\mathrm{FeO}$ の相対量 が少しずつ減少する傾向がある5)。 $570^{\circ} \mathrm{C}$ 以下の温度で は $\mathrm{FeO}$ 溔力学的に不安定で, スケールは $\mathrm{Fe}_{3} \mathrm{O}_{4} / \mathrm{Fe}_{2}$. $\mathrm{O}_{3}$ の二層より構成される。Caule ${ }^{6)}$ は $260^{\circ} \sim 470^{\circ} \mathrm{C}$ で 得られたスケール $(0.1 \sim 1.6 \mu)$ について $\mathrm{Fe}_{3} \mathrm{O}_{4} / \mathrm{Fe}_{2} \mathrm{O}_{3}$ の量の比が $1 / 3 \sim 4 / 3$ 程度にわたるととを報告している。 Gulbransen7) によれば $\mathrm{FeO}$ 層の生成の始まる最低温度 は皮膜の厚さによって左右され，皮膜がきわめて薄い場 合には $400^{\circ} \mathrm{C}$ でもその存在を認めうるという。

\section{(b) 冷却時における $\mathrm{FeO}$ の変態}

圧延が終了し，鋼板がコイルに巻き取られるときの温 度は通常 $450^{\circ} \sim 600^{\circ} \mathrm{C}$ で, 鋼板はこの状態で徐々に室 温まで泠却される。この過程においてスケールの構造は 熱圧延時とかなり異なったものに変化する。すなわち， 


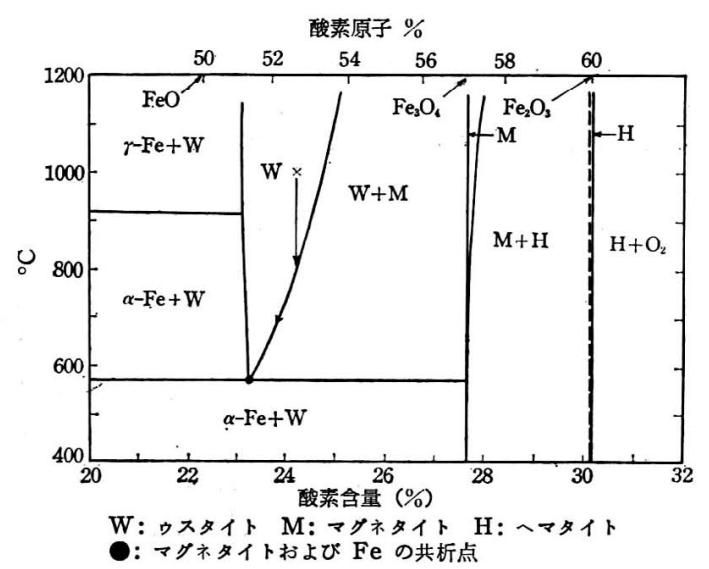

図 2 状態図

$570^{\circ} \mathrm{C}$ 以下では

$$
4 \mathrm{Fe}_{1-\boldsymbol{y}} \mathrm{O} \longrightarrow \mathrm{Fe}_{3} \mathrm{O}_{4}+(1-4 y) \mathrm{Fe}
$$

にしたがって $\mathrm{FeO}$ の変態が起こり, $\mathrm{Fe}_{3} \mathrm{O}_{4}$ と $\mathrm{Fe}$ とが 共析する1)。变態の速度は $480^{\circ} \mathrm{C}$ で最大であり,この 温度では 40〜50 分で变態が完了す るという8)。Fischer ら9,10)は bulk の $\mathrm{FeO}$ について変態の進行を $\mathrm{X}$ 線 回折および顕微鏡観察によって追跡 した結果, 冷却速度とウスタイトの 酸素含有量いかんによっては Feを 析出しない变態反応，すなわち，

$$
\begin{aligned}
& \left(1-4 y^{\prime}\right) \mathrm{Fe}_{1-\nu} \mathrm{O} \longrightarrow \\
& \quad(1-4 y) \mathrm{Fe}_{1-y}, \mathrm{O}+\left(y-y^{\prime}\right) \mathrm{Fe}_{3} \mathrm{O}_{4}
\end{aligned}
$$
が生起することを推定した。ここで $\mathrm{Fe}_{1-y}, \mathrm{O}$ は $\mathrm{Fe}$ 含量がより増大した 形のウスタイト $\left(y^{\prime}<y\right)$ であって 格子常数 $a$ 值ももとの值より大き い*1。高木 ${ }^{5)}$ によれば, 実際の圧延 スケール中においても上記の 2 種類

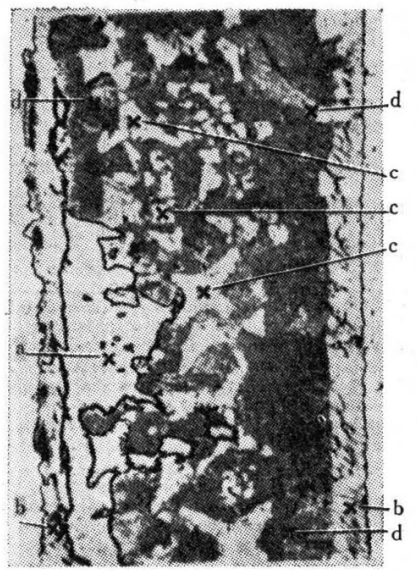

(A)

によって $\mathrm{Fe}_{2} \mathrm{O}_{3}$ の減少が起こる11 13)。このとき $\mathrm{Fe}$ は $\mathrm{FeO}$ の変態反応または地鉄よりの拡散によって補 給さ れる。実際の圧延鋼板についてもコイルの中央部のスケ ールはほとんど $\mathrm{Fe}_{2} \mathrm{O}_{3}$ を含まず,空気にふれやすい edge に近いところにその存在を認めることが多い。

\section{(c) スケールの微細構造}

Garber ${ }^{14)}$ は 2 種類のストリップミルで圧延調製した 帯鋼板上の種々の場所のスケールを顕微鏡によって観察 し，4 種の典型的な組織に分類した〔図 $3(\mathrm{~A}),(\mathrm{B}),(\mathrm{C})$, (D)]。(A) は比較的厚いスケールにみられるもので, 表 面の薄層は $\mathrm{Fe}_{3} \mathrm{O}_{4}$, 内層の地は変態した $\mathrm{FeO}$ (黒くエッ チ）でその X 線挙動は $\mathrm{Fe}_{3} \mathrm{O}_{4}$ に近く, ところどころに 析出 $\mathrm{Fe}_{3} \mathrm{O}_{4}$ 相がみられる。地鉄と接する部位は主とし て $\mathrm{FeO}$ の薄層でところどころに一次 $\mathrm{Fe}_{3} \mathrm{O}_{4}$ 相が点在 している。(B) は $\mathrm{FeO}$ 相が二つの $\mathrm{Fe}_{3} \mathrm{O}_{4}$ 層にはさまれ たサンドウィッチ型のもので, $\mathrm{Fe}_{3} \mathrm{O}_{4}$ 層が地金に接して 存在する点に特徵がある。(C) は (B) の変型であって中 央部で $\mathrm{Fe}_{3} \mathrm{O}_{4}$ 相と $\mathrm{FeO}$ 相こが縞状に入り組えだ構造を の変態が起こることが明らかであ

る。これらの $\mathrm{FeO}$ 変態反応の事情は図 2 の状態図から おおよと理解することができよう。

冷却が酸素の供給のわるい雾囲気中で起こるときには $4 \mathrm{Fe}_{2} \mathrm{O}_{3}+\mathrm{Fe} \longrightarrow 3 \mathrm{Fe}_{3} \mathrm{O}_{4}$

*1 $\mathrm{FeO}$ は岩塩型立方晶に属し, 一つの単位結晶は 4 個の $\mathrm{Fe}^{2+} 1$ オンと 4 個の O?-イオンとから構成されている。いまこの単位 結晶が 8 個集合したものを一つの結晶単位と考光れば，それに含 まれる $\mathrm{Fe}^{2+}$ および $\mathrm{O}^{2}$ イオンの数はそれぞれ 32 個である。そ こで $\mathrm{Fe}^{2+}$ イオンを 1 個ずつ格子点から抜きだし，これを $2 / 3$ 個 ずつの $\mathrm{Fe}^{3+}$ で㯰換してゆくと欠陥の程度が次第に增大し, 棈造 は結局 $\mathrm{Fe}_{3} \mathrm{O}_{4}$ を経て $r-\mathrm{Fe}_{2} \mathrm{O}_{3}$ に至る。つまり $\mathrm{Fe}_{3} \mathrm{O}_{4}$ は $\mathrm{FeO}$ の欠宿が大きくなったものにほかならない。格子常数 $2 a$ の値は $\mathrm{Fe}_{0.97} \mathrm{O}(8.62 \AA), \quad \mathrm{Fe} 0.95 \mathrm{O}(8.56 \AA), \mathrm{Fe}_{3} \mathrm{O}_{4}(\alpha=8.39 \AA), \gamma-$ $\mathrm{Fe}_{2} \mathrm{O}_{3}(a=8.30 \AA)$ のように久陥の增大ととも火減少することが 知られている（たとえば A. F. Wells: “Structual Inorganic Chemistry", 3rd Ed. p. 491 (1952) Oxford Press 育照。

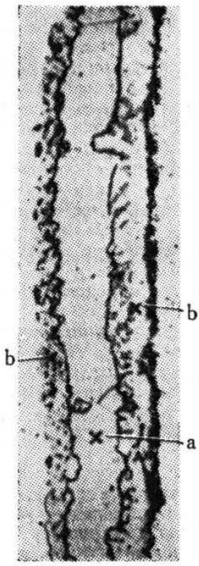

(B)

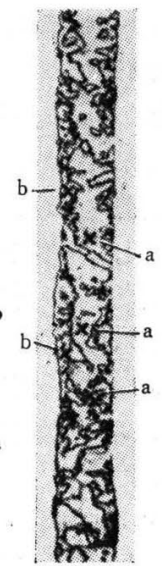

(C)

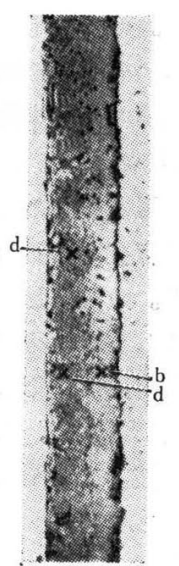

(D)
図 3 ミルスケールの顕微鏡組織 $(\times 500)$ (S. Garber) $\mathrm{a}: \mathrm{FeO}, \mathrm{b}: \mathrm{Fe}_{3} \mathrm{O}_{4}, \mathrm{c}$ : 共析 $\mathrm{Fe}_{3} \mathrm{O}_{4}, \mathrm{~d}:$ 変態 $\mathrm{FeO}$ スケール層の左側が地鉄, 右側は埋込樹脂

とっている。(D) は (A) の変型と考えられるもので最外 層は $\mathrm{Fe}_{3} \mathrm{O}_{4}$, 内層および地鉄に接する相は変態 $\mathrm{FeO}$ で その中に一次 $\mathrm{FeO}$ 相が点在する。これらの組織におい ては, $\mathrm{Fe}_{2} \mathrm{O}_{3}$ 相と析出 $\mathrm{Fe}$ 相の存在が確認されていな w。

スケールの組織に関する従来の報告を調べてみると， 研究者によって異なったものが得られている。たとえば 高木5) の得たスケールは $\mathrm{FeO}$ を含まず, $\mathrm{Fe}_{3} \mathrm{O}_{4}, \mathrm{Fe}_{2} \mathrm{O}_{3}$ および析出 $\mathrm{Fe}$ のみからなりたっており, Engell15) の 調整したものでは $\mathrm{FeO}, \mathrm{Fe}_{3} \mathrm{O}_{4}$ および $\mathrm{Fe}_{2} \mathrm{O}_{3}$ より構成 され, 析出 Fe が認められない。これらはいずれも調整 の条件が異なることによるものであり，一つの組織を得 たからといってそれがすべての場合を代表すると考える 
のは危険である。

要するにスケールの微細構造とその温度履歴との間の 関係はまだほとえど不明であって，今後系統的な研究が 望まれる現状にある。

\section{(d) スケールの機械的性質}

スケールには一般に細かい“割れ’や孔が多数存在し 酸洗の能率を高めている。これらの ‘割れ’ は圧延ロー ルのスケール破壊作用や冷却時におけるスケールの収縮 作用によって生ずるものと考えられている。前者につい てはスケールの受ける機械加工の種類と ‘つよさ’だけ でなく，スケール自身の高温時における微細構造（各種 酸化物層の分布）ならびに機械的性質（各種酸化物層お よび地鉄相互間の密着性, 硬度など）の知識を必要とす るが，これについては現在ほとんど不明である。

圧延後の鋼板冷却時においてスケール中で $\mathrm{FeO}$ (岩 塩型 $2 a=8.56 \AA$ ) $\longrightarrow \mathrm{Fe}_{3} \mathrm{O}_{4}$ (スピネル型 $a=8.37 \AA$ ) の 变態が起こるが，スケールが地鉄に接しているため，自 由収縮がきかず，地鉄とスケールの線膨張係数の差異と あいまって内部応力を生じ自ら割れを生じる傾向があ る5)。このような考えによれば, 急速冷却試料(地鉄に接 して $\mathrm{FeO}$ 相が存在する) は下地との密着性がよく, 伶 却時間を長くするほど密着性が低下するものと想像され る。

Engell ら 16)は, 熱処理試料を常温まで冷却したのち, 地鉄と直角の方向におけるスケールの引張り応力を測定 乙，これを地鉄に対する密着性または機械的破壊作用に 対する抵抗力を表わすものとした。その結果によれば $\mathrm{Si}$ などの地金中の微量元素ならびに圧延時の温度が重 要な役割りをするという。彼の取り扱ったスケールは比 較的厚いもの (数 $10 \mu$ ) で, 通常の鋼板の薄いスケール についてはこのような研究はない。

\section{(e) 酸への溶解性}

酸洗は通常インヒビターを添加した 5 〜 $25 \% \mathrm{H}_{2} \mathrm{SO}_{4}$ $\left(60^{\circ} \sim 98^{\circ} \mathrm{C}\right)$ または $5 \sim 10 \% \mathrm{HCl}\left(40^{\circ} \mathrm{C}\right.$ 内外) 中で行 なわれる。最近は $\mathrm{H}_{3} \mathrm{PO}_{4}$ 溶液も用いられるようになっ た。

スケールを構成する各種酸化物を単独で酸につけたと き，その溶解性はかなり異なっている。すなわち， $\mathrm{FeO}$ は最も溶けやすく, $\mathrm{Fe}_{3} \mathrm{O}_{4}$ はこれに次ぎ, $\mathrm{Fe}_{2} \mathrm{O}_{3}$ はほとえ ぞ溶けない。実際の酸洗過程においても，この種の選択 溶解が観察される。すなわち, Winterbottom ${ }^{17)}$ の顕微 鏡観察では，スケールの割れ目から浸入した酸はまず内 部の $\mathrm{FeO}$ 相を侵し， $\mathrm{FeO}$ 層が地鉄と接して存在する場 合には,時間とともに $\mathrm{Fe}_{3} \mathrm{O}_{4}$ および $\mathrm{Fe}_{2} \mathrm{O}_{3}$ 外層が表面か ら剩離してくる。 $\mathrm{Fe}_{3} \mathrm{O}_{4}$ が内層として存在するときには 当然陵洗が困難なことが予想されるので，圧延終了後鋼 板を $370^{\circ} \mathrm{C}$ 程度まで急速に冷却して $\mathrm{FeO}$ の $\mathrm{Fe}_{3} \mathrm{O}_{4}$ への
変態を極力おさえるような工夫も推奖されている 高木5) の報告ではこの種の冷却処理により酸洗時間を 1/3〜1/5 に短縮できるというが，急泠の効果があまり 明確でないとする研究者もいる14)。

\section{3. 局部電池作用の概略}

前述のようにスケールには多数の割れ目や孔が存在す るが, これが地鉄まで到達している場合には, 酸化物|酸 溶液|鉄という局部電池が形成され, 地鉄の溶解の儀牲 において酸化物の還元溶解が起こる。すなわち,

$$
\begin{aligned}
& \mathrm{Fe} \longrightarrow \mathrm{Fe}^{2+}+2 e \\
& \text { (a) アノード反応 } \\
& \mathrm{Fe}_{2} \mathrm{O}_{3}+6 \mathrm{H}^{+}+2 e \longrightarrow \\
& \mathrm{Fe}_{3} \mathrm{O}_{4}+8 \mathrm{H}^{+}+2 e \longrightarrow \\
& 2 \mathrm{Fe}^{2+}+3 \mathrm{H}_{2} \mathrm{O} \quad \text { (c) } \\
& \left(2 \mathrm{H}^{+}+2 e \longrightarrow \mathrm{H}_{2}\right) \\
& 3 \mathrm{Fe}^{2+}+4 \mathrm{H}_{2} \mathrm{O} \quad\left(\mathrm{c}^{\prime}\right) \\
& \text { カソード反応 }
\end{aligned}
$$

酸化物がこの種の局部電池反応にあずかるためには，そ の酸化物が $\mathrm{Fe}^{2+}$ イオンよりも価数の高いイオンを含 み，しかも十分な電気伝導性を有することが必要である。 $\mathrm{Fe}_{2} \mathrm{O}_{3}, \mathrm{Fe}_{3} \mathrm{O}_{4}$ および $\mathrm{Fe}_{1-y} \mathrm{O}$ はいずれも前者の条件を 満たしているが, 後者の条件については, $\mathrm{Fe}_{1-\nu} \mathrm{O}$ (比電 導度 $\left.1 \Omega^{-1} \cdot \mathrm{cm}^{-1}\right), \mathrm{Fe}_{3} \mathrm{O}_{4}\left(10^{2} \sim 10^{3} \Omega^{-1} \cdot \mathrm{cm}^{-1}\right), \alpha-\mathrm{Fe}_{2} \mathrm{O}_{3}$ (<10-3 $\left.\Omega^{-1} \cdot \mathrm{cm}^{-1}\right)$ であり, $\mathrm{Fe}_{2} \mathrm{O}_{3}$ はあまり問題になら ないかのようにみえる15)。しかしスケール中の $\alpha-\mathrm{Fe}_{2} \mathrm{O}_{3}$ 層は一般にきわめて薄く, ‘しかも $\mathrm{Fe}$ 過剰型の格子久陷 構造1,21) を有するので十分局部電池反応に与えるむのと 考兄られる事実, $500^{\circ} \mathrm{C}$ 以下の温度で生成したスケー ルの $\mathrm{Fe}_{2} \mathrm{O}_{3}$ 外層は容易に上記のカソード還元溶解をうけ ることが多数の人々によって検証されている6,20,21)。

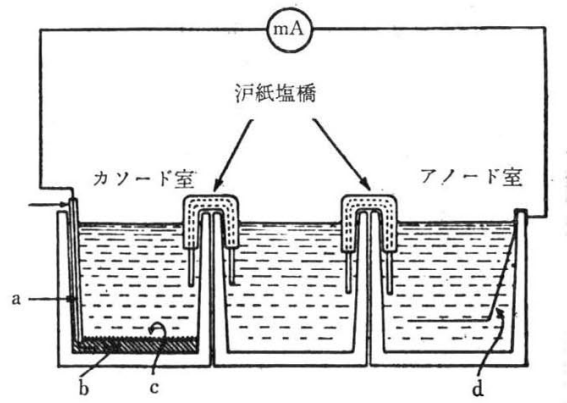

図 $4 \mathrm{Fe}_{2} \mathrm{O}_{3}$ 粉末のカソード還元溶解 (Pryor \& Evans) $\mathrm{a}: \mathrm{Pt}$ リーF, b: 水銀, $\mathrm{c}: \mathrm{Fe}_{2} \mathrm{O}_{3}$ 粉末, $\mathrm{d}: \mathrm{Fe}$ 板

Pryor, Evans ${ }^{21)}$ は種々の温度で焼成した $\alpha-\mathrm{Fe}_{2} \mathrm{O}_{3}$ を 単独で酸中に浸漬した場合ほとえど溶解しないが, これ を水銀上に浮かべてカソードとして電解するとかなりの 速度で溶解することを見いだした (図 4)。彼らはこれを スケール中の $\mathrm{Fe}_{2} \mathrm{O}_{3}$ 局部電池作用による溶解のモ デル と考えている。

Hoar ${ }^{22)}$ は，スケールの内層が $\mathrm{Fe}_{3} \mathrm{O}_{4}$ と $\mathrm{Fe}$ とに変 態しているにもかかわらず，実際の酸洗において，かな 
りの速度で溶解する事実を電気化学的に説明した。すな わち，割れ目から浸入した酸が残存する $\mathrm{FeO}$ の地を化 学的に溶解したのち, $\mathrm{Fe}_{3} \mathrm{O}_{4}$ と $\mathrm{Fe}$ の微粒が酸を仲介と して局部電池を形成し，その結果， $\mathrm{Fe}$ は $\mathrm{Fe}^{2+}$ として, $\mathrm{Fe}_{3} \mathrm{O}_{4}$ は溶解性の大きな $\mathrm{FeO}$ 型の表面構造をとって, これも $\mathrm{Fe}^{2+}$ イオンとして溶出するというのである。彼 の考えでは, $\mathrm{Fe}_{3} \mathrm{O}_{4}$ の大きな粒は反応にあずからないの で，スケールの酸洗性を向上させるためには，温度履歴 をコントロールして $\mathrm{Fe}_{3} \mathrm{O}_{4}$ および $\mathrm{Fe}$ 粒を適当なサイ ズで分散させるようにすべきである。しかしこれについ ての実験的検討はまだ行なわれていない。

金属 $\mathrm{Fe}$ が酸と接触したときに発生する $\mathrm{H}_{2}$ ガスのス ケール制離作用についてもしばしば言及されている。す なわち，古くよりの概念として，浸入した酸が地鉄およ びそれに接するスケール層を浸して両者の間に空隙をつ くり, 発生した水素の圧力で残余のスケール層の涂離が 起こるといわれている ${ }^{23)}$ 。しかし高木5) によれば，酸洗 の初期における水素発生源は地鉄よりもむしろスケール 最内層に析出した $\mathrm{Fe}$ 微粒であって，これが制離作用の 主役をするという。

さて上述の式で表わした局部電池反応が進行する際, フノード (地鉄) およびカソード（酸化物または水素で おおわれた地鉄）はそれぞれ分極されて一つの混成電位 (mixed potential) を与える。酸洗が進行しスケール被 覆面積に対する地鉄露出面積の割合が増大するにつれて 混成電位江次第に果方向に变化し, 酸洗完了とともに一 定値におちつく。图 5 にはこのような電位変化曲線 24,25$)$ と曲線の各位置に対応する模型的な局部電池分極曲線図

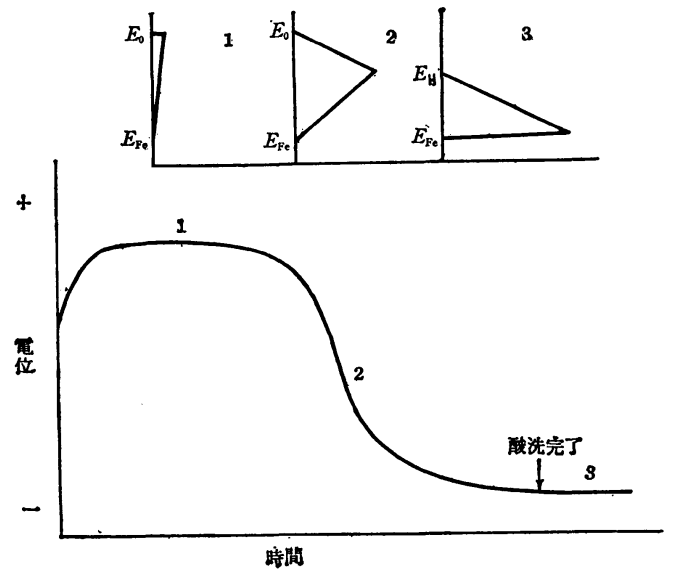

図 5 酸洗時における電位の時間的変化と局部電池模型

を示した（図 17 参照)。酸洗の過程においては，スケー ルを構成する各種酸化物がこのように種々の早電位に分 極されるのであるが， $\mathrm{Fe}_{2} \mathrm{O}_{3}$ と $\mathrm{Fe}_{3} \mathrm{O}_{4}$ の還元溶解速度 はその電位が㫗になるほど増大することが予想される。 $\mathrm{Fe}_{1-y} \mathrm{O}$ については, 還元溶解をうける $\mathrm{Fe}^{3+}$ イオン
（格子欠陌）が高々全 $\mathrm{Fe}$ 含量の 数\%に過ぎないので， 局部電池反応の溶解速度に対する寄与は僅少と想像され るのであるが，これに対し Engell らは $\mathrm{FeO}$ の溶解速 度も電位によって著しく变化する事実を認め,イオン結 晶溶解反応の一般理論を提出した。上記の各種酸化物の 溶解はすべてこれによって系統的に理解しうるので，こ れを次に説明する。

\section{4. イオン結晶溶解の理論}

通常のイオン結晶, たとえば食塩の水中への溶解にお いては, 結晶表面で起こる溶解反応がきわめて速く, 全 体の速度は溶出イオンの逸散過程によって律せられる が，多くの金属酸化物では逆に表面反応が律速的であ り ${ }^{26)}$ ，十分な電気伝導性を有するものではその溶解速度 が電位とともに変化する。前述の Pryor, Evans ${ }^{21)}$ は 電位の変化により結晶の表面構造が変化すること，そし てこれが溶解速度を左右することを初めて指摘したが， Engel127) はこれを発展させ一つの理論を提出した。

いま結晶が $\mathrm{A}^{+}, \mathrm{B}^{-}$の両イオンから構成されている とすると，その溶解反応はこれらのイオン（荷電粒子） が一つの界面を横切り固相 1 から溶液相 2 人移行するこ とに相当する。すなわち

$$
\begin{array}{l:l}
{ }_{1} \mathrm{~A}^{+} & { }_{2} \mathrm{~A}^{+} \\
{ }_{1} \mathrm{~B}^{-} & \rightarrow \\
{ }_{2} \mathrm{~B}^{-}
\end{array}
$$

ここで添字 1 および 2 はそれぞれ固相および溶液相を 意味する。反応 (1a) および (1b) は, 荷電の移行方向か ら考えると電池のアノードおよびカソード反応に対比す べきもので，それぞれの反応の速さは電流で表現するこ とができる。いまこれらの各分担反応が仮想的に全く独 立に進行するとすれば，その速度（電流）は結晶/溶液界 面の電位差（すなわち結晶の電位）の関数として変化す

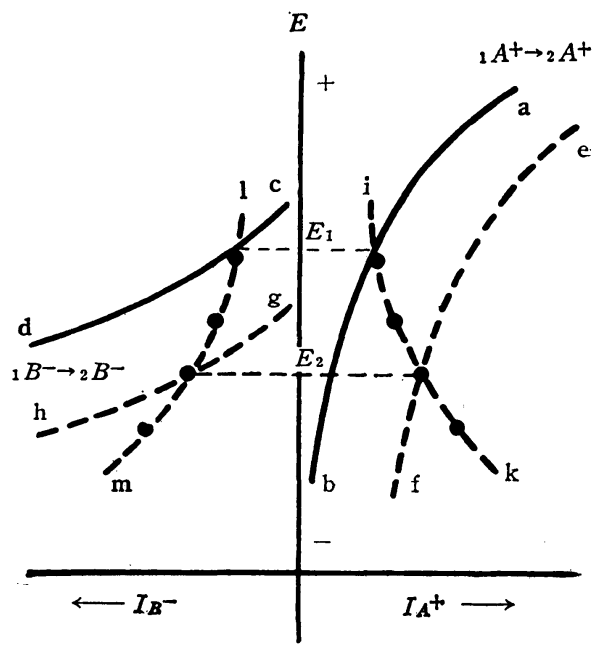

図 6 溶解分担反応の分極曲線 (Engell) 
るはずであり, 結晶表面の状態すなわち $\mathrm{A}^{+}$および $\mathrm{B}^{-}$ イオンの濃度（または化学ポテンシャル）がそれぞれ不 変であれば, 反応 (1a) および (1b) の電位電流曲線は それぞれ図 6 の ab および cd のように表わされる。ab および $\mathrm{cd}$ 曲線の電流值が等しくなる条件 (電位 $E_{1}$ ) 注 一つの定常溶解状態を表わし, ここでは曲線 ab および cd に対応する表面状態が保持されるのである。結晶表 面の状態 $\left(\mathrm{A}^{+}, \mathrm{B}^{-}\right.$イオンの化学ポテンシャル) は定常 溶解電位 $E$ の関数として变化する。すなわち,たとえ ば電位を $E_{1}$ より $E_{2}$ に下げてやると，(1 a) 反応の速 度法減少 $(1 \mathrm{~b})$ 反応の速度は増大し, その結果結晶表面 における $\mathrm{A}^{+}, \mathrm{B}^{-}$イオンの化学ポテンシャルはそれぞれ 増大および減少するのでそれに伴って電流電位曲 線が abおよび cd から移動する。定常状態では曲線 ef お よび gh に対応する表面状態をとり，両分担反応は $E_{2}$ において再び等速度で進行するようになる。このように して, 定常溶解電流の電位による变化曲線は $\mathrm{ik}$ および $\mathrm{lm}$ として表わされるのである。この両曲線はいうまで もなく電位軸をはさんで対称の位置にある。

以上の概念を数式によって定量的に表現すると次のよ うである。まず上記の $\mathrm{ab}$ および $\mathrm{cd}$ 曲線はそれぞれ次 の電極反応速度式によって表現することができる。

$$
\begin{aligned}
I_{A^{+}}= & { }_{1} k_{A} \cdot{ }_{1} C_{A} \exp \left\{\alpha_{A} Z_{A} F E / R T\right\} \\
& -{ }_{2} k_{A^{*}} \cdot{ }_{2} C_{A} \exp \left\{-\left(1-\alpha_{A}\right) Z_{A} F E / R T\right\} \\
I_{B^{-}}= & { }_{1} k_{B} \cdot{ }_{1} C_{B} \exp \left\{\alpha_{B} Z_{B} F E / R T\right\} \\
& -{ }_{2} k_{B} \cdot{ }_{2} C_{B} \exp \left\{-\left(1-\alpha_{B}\right) Z_{B} F E / R T\right\}
\end{aligned}
$$

ここで $k$ : 反応速度定数, $C$ : 濃度, $\alpha$ : 透過係数,

$Z$ : イオン価数, $F:$ ファラディ定数, $E:$ 電位, $R:$ 気 体定数, $T$ : 絶対温度, 1 および 2 は固相および溶液 相を意味する。

これらの式の右辺の第 1 項は溶解反応電流，第 2 項は 析出反応電流を表わしており, その差額が正味の溶解電 流 $I$ になる。与えられた電位 $E$ が反応 (1a) および (1b) の平衡電位よりも十分に離れていれば，第 2 項は 無視しうる。表面イオン濃度 ${ }_{1} C$ は熱力学の法則より

$$
\begin{aligned}
& \left.{ }_{1} C_{A}=\exp \left\{{ }_{1} \mu_{A}-{ }_{1} \mu_{A}^{\circ}\right) / R T\right\} \\
& \left.{ }_{1} C_{B}=\exp \left\{{ }_{1} \mu_{B}-{ }_{1} \mu_{B}^{\circ}\right) / R T\right\}
\end{aligned}
$$

ここで $\mu^{\circ}$ は $C=1$ におけるそのイオンの化学ポテンシ ヤル（標準化学ポテンシャル）。いま

$$
\begin{aligned}
& { }_{1} k_{A}^{\circ}={ }_{1} k_{A} \exp \left(-{ }_{1} \mu_{A}^{\circ} / R T\right\} \\
& { }_{1} k_{B}^{\circ}={ }_{1} k_{B} \exp \left(-{ }_{1} \mu_{B}^{\circ} / R T\right\}
\end{aligned}
$$

とおき，(3) (4)を(2a) および (2b) 式に入れて整理す れば [(2) 式の第 2 項は無視する],

$$
\begin{aligned}
& I_{A^{+}}={ }_{1} k_{A}^{\circ} \exp \left\{\left(\alpha_{A} Z_{A} E F+{ }_{1} \mu_{A}\right) / R T\right\} \\
& I_{B^{-}}={ }_{1} k_{B}^{\circ} \exp \left\{\left(\alpha_{B} Z_{B} E F+{ }_{1} \mu_{B}\right) / R T\right\}
\end{aligned}
$$

前述のように ${ }_{1} \mu_{A}$ および ${ }_{1} \mu_{B}$ は与えられた定常電位 の関数であるが, その関係は次のようにして求められる。
すなわち，定常溶解状態の条件として

$$
I_{A^{+}}=I_{B^{-}}
$$

また結晶の表面構造が化学量論的なものからあまり著し く変化しない範囲では, 熱力学の法則より

$$
{ }_{1} \mu_{A}+{ }_{1} \mu_{B}={ }_{1} \mu_{A B}=\text { const }
$$

${ }_{1} \mu_{A B}$ は問題の結晶の化学ポテンシャル (Gibbs の生成 自由エネルギー）であって電位に依存せず常に一定の值 をもつ。(5)，(6) および (7) より

$$
\begin{aligned}
{ }_{1} \mu_{A}= & 1 / 2 \cdot\left\{1 \mu_{A B}+R T \ln \left({ }_{1} k_{B}^{\circ} /{ }_{1} k_{A}^{\circ}\right)\right. \\
& \left.+\left(\alpha_{B} Z_{B}-\alpha_{A} Z_{A}\right) E F\right\} \\
{ }_{1} \mu_{B}= & 1 / 2 \cdot\left\{{ }_{1} \mu_{A B}+R T \ln \left({ }_{1} k_{A}^{\circ} /{ }_{1} k_{B}^{\circ}\right)\right. \\
& \left.-\left(\alpha_{B} Z_{B}-\alpha_{A} Z_{A}\right) E F\right\}
\end{aligned}
$$

（8）を（5）に代入して整理し， $Z_{B}=-\left|Z_{B}\right|$ を考虑すれ ば,

$$
\begin{aligned}
I= & \left|I_{A}\right|=\left|I_{B}\right|=\sqrt{{ }_{1} k_{A}^{\circ} \cdot 1 k_{B}^{\circ}} \exp \left({ }_{1} \mu_{A B} / 2 R T\right) . \\
& \exp \left\{\left(\alpha_{A}\left|Z_{A}\right|-\alpha_{B}\left|Z_{B}\right|\right) E F / 2 R T\right\}
\end{aligned}
$$

これは図 6 の曲線 $\mathrm{ik}$ および $\mathrm{lm}$ の関係式にほかならな い。両辺の対数をとって $E$ で微分すると，

$$
d \ln I / d E=\left(\alpha_{A}\left|Z_{A}\right|-\alpha_{B}\left|Z_{B}\right|\right) F / 2 R T
$$

すなわち，イオン結晶の溶解においても Tafel の関係 $(E$ と $\ln I$ との直線関係) が成立する訳である。ここで $\alpha_{A}\left|Z_{A}\right|>\alpha_{B}\left|Z_{B}\right| \cdots$ 電位上昇とともに溶解速度が増大 $\alpha_{A}\left|Z_{A}\right|<\alpha_{B}\left|Z_{B}\right| \cdots$ 電位上昇とともに溶解速度が減小 $\alpha_{A}\left|Z_{A}\right|=\alpha_{B}\left|Z_{B}\right| \cdots$ 電位を変えても溶解速度が変らない (10) 式は両分担反応がともにその平衡から十分離れた状 態で進行している場合に相当するが，次にその一方たと えば (1a) 反応の交換速度（電流）が大きく，この反応 が平衡からこくわずか外れた状態で進行している場合を 考察する。すなわち (2a) 式を(5a) 式のように表わし， 第 1 項および第 2 項の值が大きくてしかもほとんど等し いと考えれば

$$
\frac{{ }_{1} k_{A}^{\circ} \exp \left\{\left(\alpha_{A} Z_{A} F E+{ }_{1} \mu_{A}\right) R T\right\}}{{ }_{2} k_{A}^{\circ} \exp \left[\left\{-\left(1-\alpha_{A}\right) Z_{A} F E-{ }_{2} \mu_{A}\right\} / R T\right]} \approx 1
$$

これより

$$
{ }_{1} \mu_{\boldsymbol{A}} \approx \approx_{2} \mu_{A}-Z_{A} F E+R T \ln \left({ }_{2} k_{A}^{\circ} /{ }_{1} k_{A}^{\circ}\right)
$$

これを (7) とともに (5b) 式に代入し, 対数をとって 微分すると,

$$
\begin{aligned}
d \ln I / d E & =d \ln I_{B^{-}} / d E \\
& \approx\left(\left|Z_{A}\right|-\alpha_{B}\left|Z_{B}\right|\right) F / R T
\end{aligned}
$$

逆に (1b) 反応が平衡に近い状態で進行するときには, $d \ln I / d E=d \ln I_{A^{+}} / d E$

$$
\approx\left(\alpha_{A}\left|Z_{A}\right|-\left|Z_{B}\right|\right) F / R T
$$

上記の (10)，(11) および (12) 式で表わされる三つの溶 解型式に対し，透過係数 $\alpha_{A}$ および $\alpha_{B}$ がいずれも 0.3 $\sim 0.7$ の範囲にあると仮定すれば, 酸化物結晶 $\mathrm{MeO}\left(Z_{\boldsymbol{A}}\right.$ $\left.=2, Z_{B}=-2\right)$ について, $b=d E / d \ln I$ の值は

(10) 式: $\alpha_{A}>\alpha_{B}$ のとき $b \geqq+0.064 \mathrm{~V}$ 
$\alpha_{A}<\alpha_{B}$ のとき $b \leqq-0.064 \mathrm{~V}$

(11) 式: $+0.017<b<+0.043 \mathrm{~V}$

(12) 式: $-0.043<b<-0.017 \mathrm{~V}$

これらの関係を模型的に図 7 に示す。

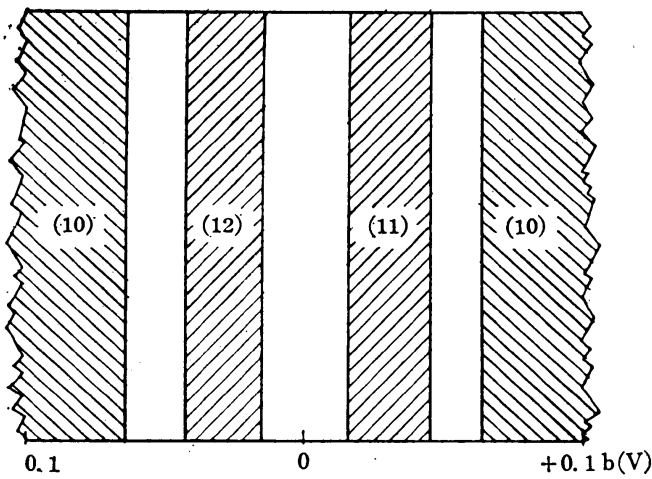

図 $7 \mathrm{~b}$ 值之溶解反応の型式 （）内の数字は本文中の式の番号を示す

上述の Engell の理論でもっとも重要な点は, 与えら れた電位に応じて結晶表面を構成する二つの対立イオン の濃度が変化し, それに伴って結晶の溶解速度が変化す るということであるが，最近著者の一人 ${ }^{28)}$ む類似の概念 を $\mathrm{Fe}$ 不働態の研究に適用している。この種の表面欠陌 構造はもちろん結晶の内部に対して非平衡の 状 態にあ り, 結晶の内部からまたは結晶内部に向ってイオンの拡 散が起こって平均化しょうとする傾向がある。しかし， 通常結晶内イオン拡散速度は溶解速度（したがって久陌 を生ずる速度）に比べて著しく小さいので溶解の定常状 態では与えられた表面欠陷構造を保持しうるのである。

\section{5. 鉄酸化物の溶解特性}

Engel127）は上述の理論を検証するため, 溶融処理によ って $\mathrm{FeO}$ および $\mathrm{Fe}_{3} \mathrm{O}_{4}$ 電極を調整し (表 1 ), $1 \mathrm{NH}_{2}$. $\mathrm{SO}_{4}$ および $1 \mathrm{~N} \mathrm{HCl}$ 中において溶解速度と電位との関 係を求めた。その結果をそれぞれ図 8 および図 9 に示 す。

$1 \mathrm{~N}_{2} \mathrm{SO}_{4}\left(25^{\circ} \mathrm{C}\right)$ 中の $\mathrm{FeO}$ の場合には，溶解電流*2 の対数と電位との間に直線関係が成立し，その傾きは

$$
b=d E / d \ln I=-0.080 \mathrm{~V}
$$

$Z_{A^{+}}=+2, Z_{B^{-}}=-2$ を考虑するとこれは (10) 式の成立 する場合に相当し*3，(10) 式より

$$
\left(\alpha_{B^{-}}-\alpha_{A^{+}}\right)=\left(\alpha_{02}--\alpha_{\mathrm{Fe}^{2}+}\right)=0.32
$$

*2 固/液界面を横切って移行する $\mathrm{Fe}^{2+}$ イオンに注目し Faraday の法剈を用いて溶解速度を電流に換算する。すなわち， $I=F W Z / M A t \quad\left(\mathrm{~A} / \mathrm{cm}^{2}\right)$

$F: 96,500$ (coulomb/equi.), $W:$ 溶出 $\mathrm{Fe}^{2+}$ イオン量 $(\mathrm{g})$, $M: \mathrm{Fe}$ の原子量 $(\mathrm{g} / \mathrm{mol}), t:$ 時間 $(\mathrm{sec}), A:$ 電極面積 $\left(\mathrm{cm}^{2}\right)$ $Z$ : 荷電数 (equi $/ \mathrm{mol}$ ここでは 2)。したがって $\mathrm{Fe} \longrightarrow \mathrm{Fe}^{2+}$ なる電極反応の電流の表現と同一である。

*3 溶解分担反応は, ${ }_{1} \mathrm{Fe}^{2+} \longrightarrow{ }_{2} \mathrm{Fe}^{2+}$ および ${ }_{1} \mathrm{O}^{2-}+{ }_{2} \mathrm{H}^{+} \longrightarrow{ }_{2} \mathrm{OH}^{-}$ または ${ }_{1} \mathrm{O}^{2-}+2_{2} \mathrm{H}+\longrightarrow{ }_{2} \mathrm{H}_{2} \mathrm{O}$

\begin{tabular}{|c|c|c|c|c|}
\hline \multirow{2}{*}{ 酸 化 物 } & \multicolumn{4}{|c|}{ 分 析 值 (\%) } \\
\hline & $\mathrm{FeO}$ & $\mathrm{Fe}_{2} \mathrm{O}_{3}$ & $\mathrm{Fe}$ & 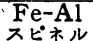 \\
\hline $\begin{array}{l}\mathrm{FeO} \\
\mathrm{Fe}_{3} \mathrm{O}_{4}\end{array}$ & $\begin{array}{l}87.1 \\
40.0\end{array}$ & $\begin{array}{l}11.1 \\
54.9\end{array}$ & 1.6 & 5.1 \\
\hline
\end{tabular}

表 $1 \mathrm{FeO}$ および $\mathrm{Fe}_{3} \mathrm{O}_{4}$ 試料の分析值 (Engell)

* 調製法: $\mathrm{FeO} \cdots \cdots \cdot \mathrm{Fe}_{2} \mathrm{O}_{3}$ を鉄ルッボ中で $1,450^{\circ} \mathrm{C}$ 飞加熱溶虽し銅 鏻型 $(5 \mathrm{~mm} \phi)$ に流しこむ。

$\mathrm{Fe}_{3} \mathrm{O}_{4} \cdots \cdots$...計算量の $\mathrm{Fe}_{2} \mathrm{O}_{3}$ と $\mathrm{Fe}$ とをてルミナルッボ中 $1,500^{\circ} \mathrm{C}$ で溶融し銅鏻型飞流しこむ。

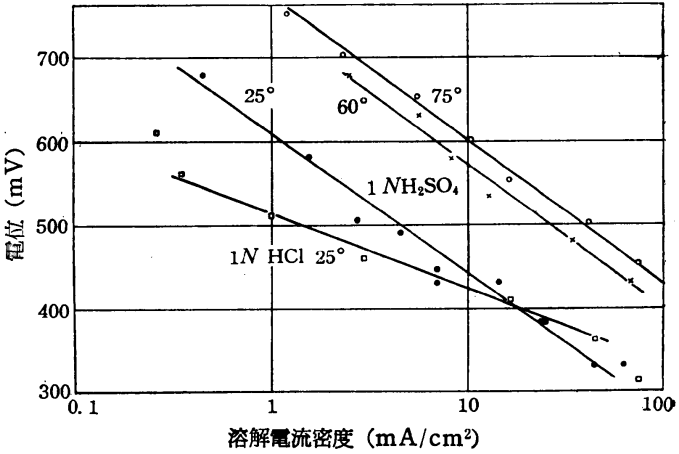

図 $8 \mathrm{FeO}$ の溶解電流の電位による变化 (Engell)

したがって $\alpha$ が $0.3 \sim 0.7$ の範囲内にあ るという前項 の仮定は一応 妥当である。 温度が $60^{\circ} \mathrm{C}$ および $75^{\circ} \mathrm{C}$ の場合にも類 似の結果が得 られる。ただ しこの実験で は電位領域 が $+300 \sim+$ $750 \mathrm{mV}$ (vs. NHE) に限定 されている

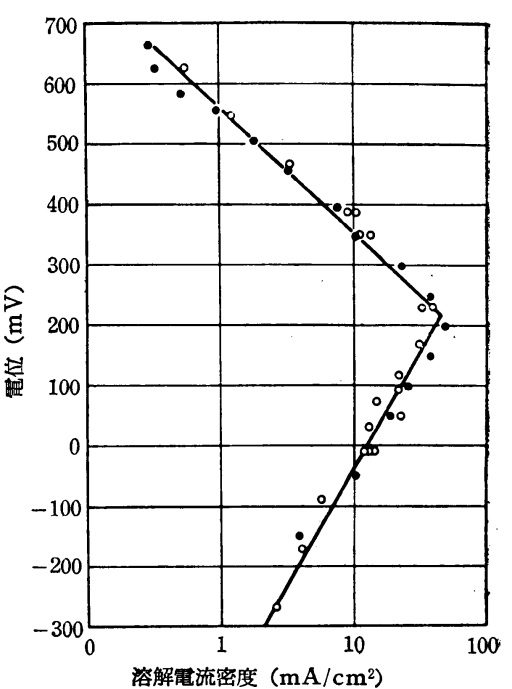

図 $9 \quad \mathrm{Fe}_{3} \mathrm{O}_{4}$ の溶解電流と電位との関係 (Engell)
が，これより低い電位領域では曲線の形が複 雑になる (図 15 および図 16 参照)。1 $\mathrm{N} \mathrm{HCl}\left(25^{\circ} \mathrm{C}\right)$ 中の $\mathrm{FeO}$ の 場合には $b=-0.039$ で, これは (12) 式の成立する場 合であって $\alpha_{\mathrm{Fe}^{2+}}=0.67$ をうる。これも一応妥当な数字 である。

$1 \mathrm{NH}_{2} \mathrm{SO}_{4}\left(75^{\circ} \mathrm{C}\right)$ 中の $\mathrm{Fe}_{3} \mathrm{O}_{4}$ については, $+215 \mathrm{mV}$ を境として二つの折れ曲った直線になる。すなわち，こ れより高電位および低電位の領域において電位低下とと もに溶解速度がそれぞれ増大および減少する。b 值はそ れぞれ $-0.091 \mathrm{~V}$ および $+0.166 \mathrm{~V}$ であって，いずれ 
も（10）式の成立する場合に相当する。この場合, 相境 界を横ぎる $\mathrm{Fe}$ イオンが 2 価と仮定すれば，上記のそれ ぞれの電位領域で

$$
\begin{aligned}
& \left(\alpha_{\mathrm{Fe}^{2+}-} \alpha_{\mathrm{o}^{2-}}\right)=-0.28 \mathrm{~V} \text { および } \\
& \left(\alpha_{\mathrm{Fe}^{2+}-} \alpha_{\mathrm{0}^{2-}}\right)=+0.156 \mathrm{~V}
\end{aligned}
$$

となる*4。

さて，上述のように酸化物電極を分極して種々の電位 を与えるためには適当な外部分極回路が必要であるが， その際試料の電位の関数としてこの回路を種々の電流が 流れる。この電流を電子電流 (electron current) とよ ぶことにする。 $1 \mathrm{~N} \mathrm{H}_{2} \mathrm{SO}_{4}\left(25^{\circ} \mathrm{C}\right)$ 中の $\mathrm{FeO}$ 電極 の場 合，電子電流と電位との関係は図 10 のようになる。自 然電位 $+440 \mathrm{mV}$ よりも貴電位の領域で流れる 小さな アノード電流はおそらく $\mathrm{Fe}^{2+} \longrightarrow \mathrm{Fe}^{3+}+e$ なる反応に 対応し, $+1,800 \mathrm{mV}$ 以上での大きなつノード電流は

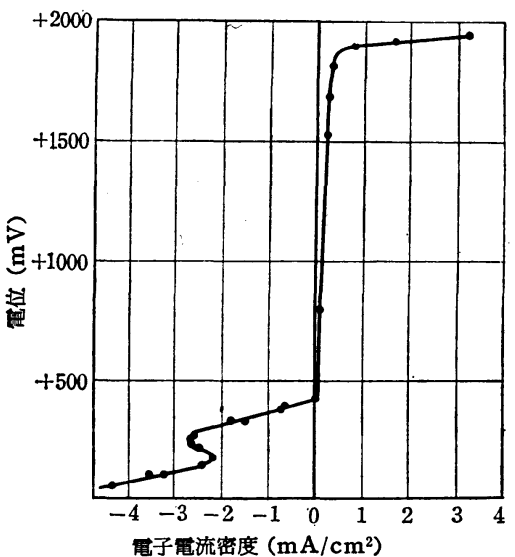

図 $10 \mathrm{FeO}$ の電子電流と電位との関係

(Engell)

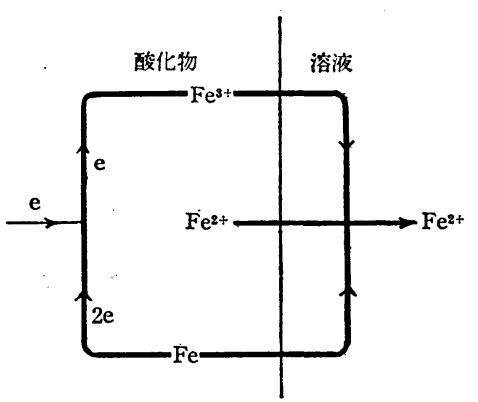

図 11 電子電流と溶解電流との関係
酸素発生に基 ゔくものであ るが, 酸洗の 条件で問題に なるのは，自 然電位よりも 低い電位域で ある（次項参 照)。この領 域で流れるカ ソード電子電 流の内容は図 11 に模型的 に示したよう に, $\mathrm{FeO}$ に含 まれる不純物 金属 $\mathrm{Fe}$ およ び $\mathrm{Fe}^{3+}$ イオ ソの $\mathrm{Fe}^{2+}$ イ オンへの酸化 および還元反 応の電流（後 者が大）に基 ゔくものと考

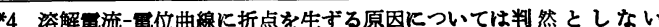
が,一応溶解分担反店の型式か変化したるのと考える。たとえば

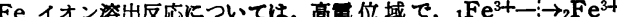
$\longrightarrow \mathrm{Fe}^{2+}$, 低電位域て ${ }_{1} \mathrm{Fe}^{3+} \longrightarrow \mathrm{Fe}^{2+}$ 一 $\rightarrow_{2} \mathrm{Fe}^{2+}$ また 0 イオ

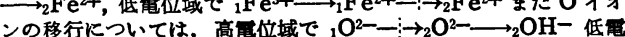
位域で $\mathrm{O}^{2-} \longrightarrow \mathrm{OH}_{1}$ - $\rightarrow_{2} \mathrm{OH}$-のごときである。このよ5な説 明は図 14 および図15 の結果についてる墖用できるが,いまのとこ ろ実証の手段がない。

*5 全浴解電流 $I_{\mathrm{Fe}} 2+$ のろち $\mathrm{Fe}^{3+}$ イオンの逗元溶解反応および $\mathrm{Fe}$

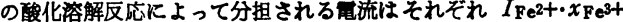

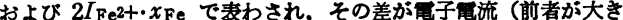
く正味ではカンード雨流)の2 倍に相当する。2倍になる理由は $I_{\mathrm{Fe}}^{2+}$ の值をきめるとき谘解反応を 2 電子反応と見なしたからで ある (*2 照)
えられる。したがって，ある与えられた電位における電 子電流と電解電流との間には次の関係が成立する*5。

$$
2 I_{\mathrm{e}}=I_{\mathrm{Fe}^{2+}}\left(x_{\mathrm{Fe}^{3+}}-2 x_{\mathrm{Fe}}\right)
$$

ただし， $x_{\mathrm{Fe}^{3+}}$ および $x_{\mathrm{Fe}}$ はそれぞれ $\mathrm{Fe}^{3+}$ イオンお よび金属 $\mathrm{Fe}$ 含量をモル分率で表わしたもの。表 1 の分 析值からこれらの值を算出すると $I_{0} / I_{\mathrm{Fe}^{2+}}{ }^{2+} 0.03$ とな る。実測の結果は電位に無関係にほぼこの值と一致して いる(図 12)。

$\mathrm{Fe}_{3} \mathrm{O}_{4}$ については同様に,

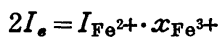

の関係が成立するが，この場合も $I_{*} / I_{\mathrm{Fe}} 2+$ の実測值は 分析值から求めた理論值 (36\%) とかなりよく一致して いる(図 13)。この種の方法は,一般にイオン結晶の化学 量論的組成からの ‘ずれ’を決定する方法として使用す ることができる29)。

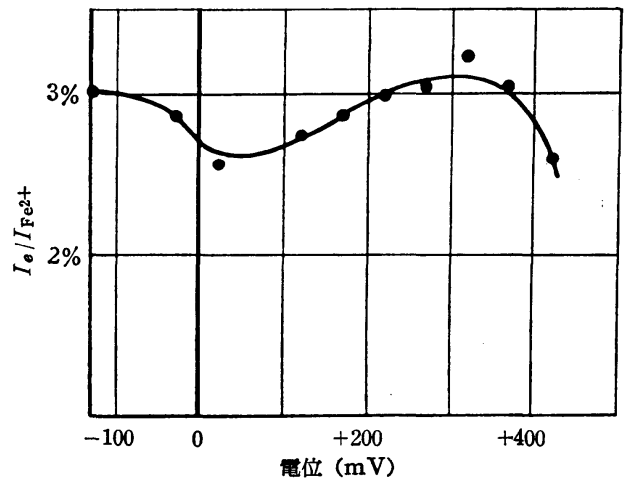

図 $12 \mathrm{FeO}$ の $I_{e} / I_{\mathrm{Fe}^{2+}}$ 值の電位による変化 (Engell)

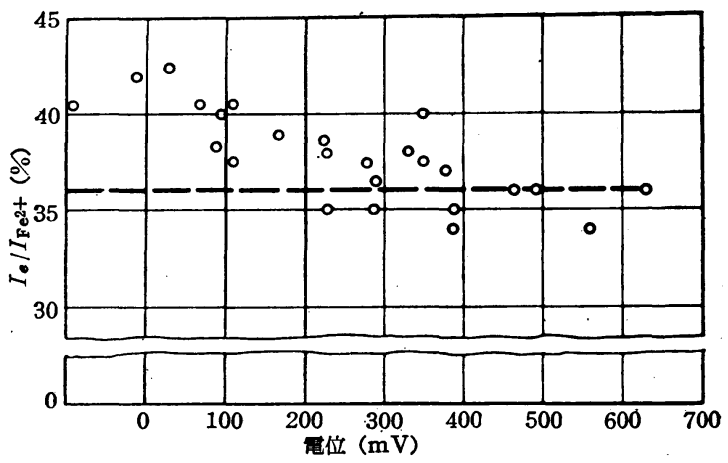

図 $13 \mathrm{Fe}_{3} \mathrm{O}_{4}$ の $I_{6} / I_{\mathrm{Fe}^{2+}}$ 值と電位との関係 (Engell)

\section{6. $\mathrm{Fe} \mid \mathrm{FeO}$ 電池の举動}

圧延スケールを酸洗する際，スケールには常に“割 れ’が存在するので $\mathrm{Fe}$ と酸化物との間には一つの電池 が形成され，それによって酸化物の電位が規正されるの でその溶解速度に著しい影響がある。Engell, Wever ${ }^{15)}$

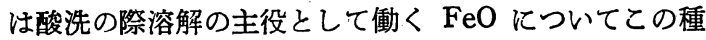
の電池挙動を調べた。

すなわち，まず図 14 の装置を用い $1 \mathrm{NH}_{2} \mathrm{SO}_{4}\left(25^{\circ} \mathrm{C}\right)$ 


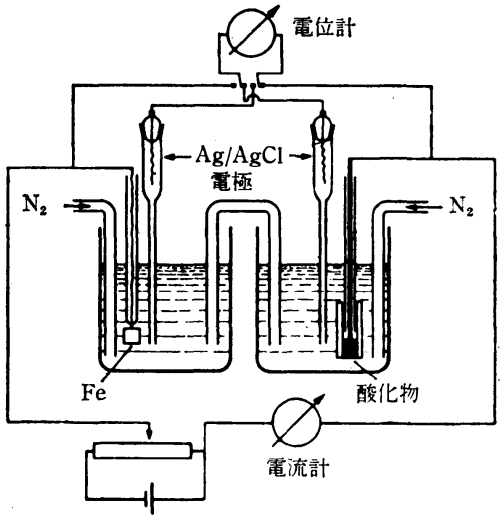

図 14 実験装置
中において, $\mathrm{FeO}$ おび Fe のそれぞ れについてカ ソードおよび アノード分極 曲 線(電子電 流一電位曲線） を測定すると 図15のよう になる。その 際, これらの 曲線はそれぞ

れ反応

$$
\begin{array}{ll}
2 \mathrm{Fe}_{1} \mathrm{Fe}^{+}+2 e \longrightarrow 2{ }_{2} \mathrm{Fe}^{2+} & \text { (カソード反応 }) \\
{ }_{1} \mathrm{Fe} \longrightarrow{ }_{2} \mathrm{Fe}^{2+}+2 e & \text { (アノード反応 }
\end{array}
$$

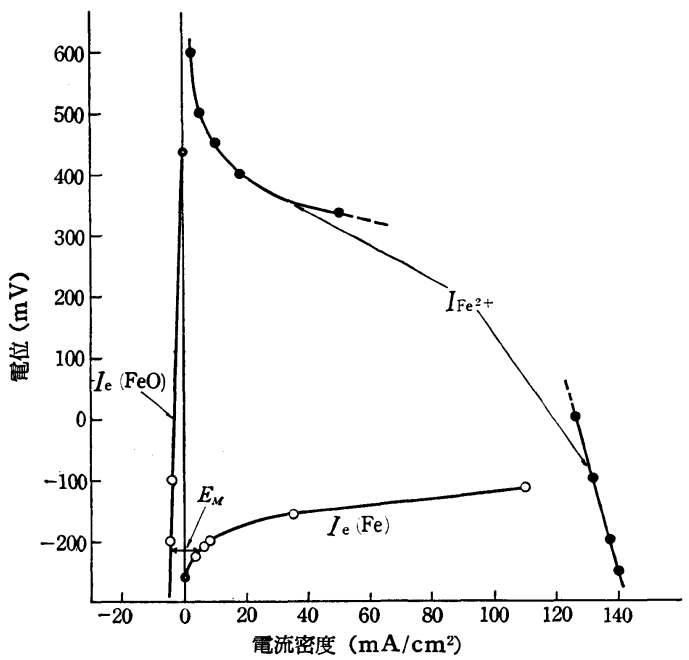

図 $15 \mathrm{Fe}, \mathrm{FeO}$ の電子電流および $\mathrm{FeO}$ の溶解電 流の電位による变化

(1 $\mathrm{NH}_{2} \mathrm{SO}_{4}, 25^{\circ} \mathrm{C}$ ) (Wever, Engell より)

の速度に対応しており, $\mathrm{FeO}$ および $\mathrm{Fe}$ の自然電位(それ ぞれ $+440 \mathrm{mV}$ および $-250 \mathrm{mV}$ ) ではこれらの反応が ほとんど停止している*6。この分極曲線図から判断しう るように, $\mathrm{FeO}$ および $\mathrm{Fe}$ の表面積を等しくとってこれ を短絡すれば，それぞれの電位はともに $E_{\boldsymbol{M}}=-215 \mathrm{mV}$ におちつく。これは上記の両反応の混成電位 (mixed potential) に相当する。この際， $E_{\boldsymbol{M}}$ の值は $\mathrm{FeO}$ 中の

*6 $\mathrm{FeO}$ の自然電位は ${ }_{1} \mathrm{Fe}^{3+}+e \rightleftarrows{ }_{2} \mathrm{Fe}^{2+}$ の平衡電位 ${ }^{28)}, \mathrm{Fe}$ の自然 電位は ${ }_{1} \mathrm{Fe} \longrightarrow \mathrm{Fe}_{2} \mathrm{Fe}^{2+}+2 e, 2_{2} \mathrm{H}++2 e \longrightarrow \mathrm{H}_{2} \mathrm{H}_{2}$ の混成電位と考光 られるが,この形式による Fe の自己溶解電流の寄与は比䡈的小 さいので简単のために無規している。

*7 $\mathrm{Fe}^{2+}$ イオンの移動のみに注目しているので溶解電流をアノード電 流軸にとった。O2-イオンに注目すればカソード電流軸にとれば よい。その際, 溶解電流曲線は電位軸に関し対称の位置をとる（図 6 参。
$\mathrm{Fe}^{3+}$ イオン濃度の関数である。すなわち, しし $\mathrm{FeO}$ の 溶解電流曲線（後述）が不变であると仮定すれば， $\mathrm{Fe}^{3+}$ 濃度の增大によって上記のカソード分極曲線が左方に移 動するので $E_{M}$ の值はより貴の方向に変化するであろ う。また $E_{\boldsymbol{M}}$ の值は $\mathrm{Fe}$ と $\mathrm{FeO}$ との面積比によっても 大幅に変化すると考えられる。事実, 酸洗の行程におい て, 初期には酸化物がほとえど全面をおおっており, 次 第に $\mathrm{Fe}$ 面が拡大して終には酸化物が消滅するので， $E_{M}$ の值は著しく貴な值から $\mathrm{Fe}$ の自然電位に向って変 化する (図 5 参照)。その際，スケールが $\mathrm{FeO}$ のみから なりたつものと仮定すれば，上記のように+440 mV $\longrightarrow-250 \mathrm{mV}$ の变化をする訳である。

図 15 にはこの電位領域における $\mathrm{FeO}$ の溶解電流-電 位曲線をも示してある*7。前述の図 8 の関係は +300 $\mathrm{mV}$ 以上の電位域に限定されているので，この場合は役 に立たない。なお図 16 にも示すように，溶解電流一電位 曲線は $+300 \mathrm{mV}$ 以下では複雑な形となり,しかもイン ヒビターの存在によってかなりの影響をうける。

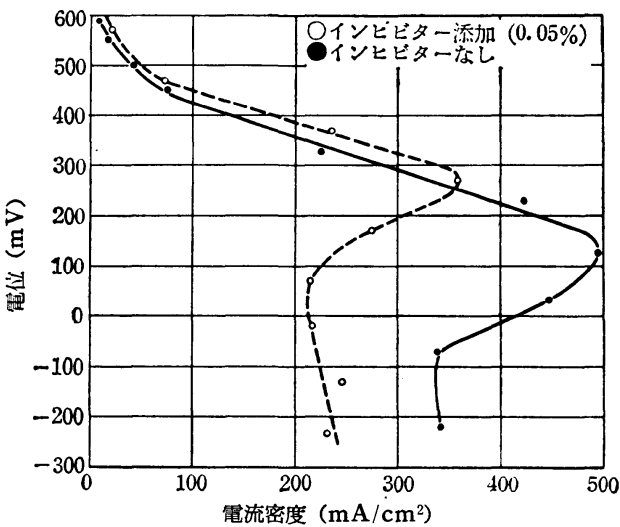

図 $16 \mathrm{FeO}$ の溶解電流に対するインヒビターの影響 $1 \mathrm{NH}_{2} \mathrm{SO}_{4}, 75^{\circ} \mathrm{C}$ (Engell)

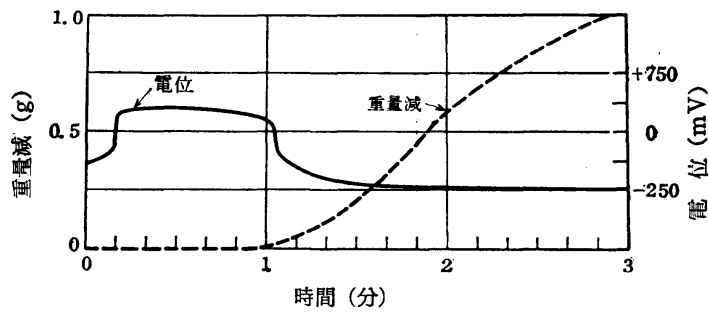

図 17 酸洗時における $E_{M}$ および重量の時間的变化 $15 \% \mathrm{H}_{2} \mathrm{SO}_{4}, 60^{\circ} \mathrm{C}$, インヒビター 0.05\% 添加 (Engell, Wever)

さて Engell ら 15,25) は, 熱処理した試料をインヒビタ 一を含む $15 \% \mathrm{H}_{2} \mathrm{SO}_{4}$ 溶液 $\left(60^{\circ} \mathrm{C}\right)$ 中に浸漬し, 自記記 録装置によって試料の重量減少と電位の時間的变化を追 跡した (図 17)。電位は浸漬後まもなく+420 $\mathrm{mV}$ 程度 の高電位に到達し暫時この電位を保つが，この状態では 試料の重量減はほとんど認められない。電位が低下し始 
めるとともに重量が減少し始め,電位が約 $-250 \mathrm{mV}$ の 定常電位に近づくとともに重量減少の速度が低下してく る。この結果は酸化物を $\mathrm{FeO}$ にった図 15 のモデル 実験の結果と定性的に一致している。すなわち，高電位 域（全面が酸化物で被覆された状態）では酸溶液が微細 な割れ目から浸入して酸化物と接触してもとの溶解速度 は無視しうるほど小さいが， Fe の露出面が増大して電 位が低下するとともに酸化物の溶解速度は著しく増加す るのである。酸化物の全く消滅した状態（電位は -250 $\mathrm{mV}$ の定常位) では，水素発生を伴う $\mathrm{Fe}$ の自己溶解が 定常的に進行している。

以上を要するに，酸洗に際して酸化物および $\mathrm{Fe}$ 電極 を流れる電子電流の相対的な大いさが酸化物の電位を決 定し,その電位に基づいて酸化物の自己溶解が進行する。 溶解電流と電位との関係は酸化物および溶液の両者の性 質によってきめられるのである*8。

\section{7. 酸洗損失の概念}

Engell, Wever ${ }^{15)}$ は, $\mathrm{FeO}$ と $\mathrm{Fe}$ 電極の面積をそれ ぞれ $1 \mathrm{~cm}^{2}$ に限定した短絡電池（図 13 参照）をつくっ てこれを酸洗の一つのモデルとし，溶液の種類および温 度を変化してその挙動を調べた。その結 果を表 2 に示

表 2 モデル実験の結果 (Wever, Engell)

\begin{tabular}{|c|c|c|c|c|c|c|c|c|}
\hline 酸 & $\begin{array}{c}\text { 酸篧度 } \\
\text { 重 量 } \\
\%\end{array}$ & $\begin{array}{l}\text { 温度 } \\
{ }^{\circ} \mathrm{C}\end{array}$ & $\begin{array}{c}\text { インヒ } \\
\text { ビター } \\
\text { 添加量 } \\
\%\end{array}$ & $\begin{array}{l}\text { 溶解 } \\
\text { 電流 } \\
\mathrm{A} / \mathrm{m}^{2}\end{array}$ & $\left|\begin{array}{c}\text { 電子電流 } \\
\text { の溶解電 } \\
\text { 流に対す } \\
\text { る割合 } \\
\%\end{array}\right|$ & $\begin{array}{l}\text { 電位 } \\
\mathrm{mV}\end{array}$ & $\begin{array}{l}\text { 浴解速度 } \\
\mathrm{g} / \mathrm{m}^{2} \text { min }\end{array}$ & $\begin{array}{c}\text { 酸洗 } \\
\text { 損失 } \\
\% \\
\%\end{array}$ \\
\hline $\mathrm{HCl}$ & $\begin{array}{l}18 \\
18 \\
12 \\
12 \\
24 \\
24 \\
18 \\
18 \\
12 \\
12\end{array}$ & $\begin{array}{l}20 \\
20 \\
20 \\
20 \\
47 \\
47 \\
47 \\
47 \\
47 \\
47\end{array}$ & $\begin{array}{l}\overline{0.05} \\
\overline{0.05} \\
\overline{0.05} \\
\overline{0.05} \\
\overline{0.05}\end{array}$ & $\begin{array}{r}5,200 \\
4,360 \\
2,850 \\
1,265 \\
10,350 \\
5,730 \\
10,630 \\
6,030 \\
7,300 \\
7,200\end{array}$ & $\begin{array}{l}3.0 \\
3.3 \\
3.3 \\
3.8 \\
3.1 \\
2.9 \\
2.6 \\
2.9 \\
2.9 \\
2.8\end{array}$ & $\begin{array}{l}-159 \\
-84 \\
-157 \\
-48 \\
-185 \\
-159 \\
-181 \\
-121 \\
-181 \\
-98\end{array}$ & $\begin{array}{r}116.0 \\
103.0 \\
63.6 \\
28.3 \\
231.0 \\
128.0 \\
237.0 \\
135.0 \\
163.0 \\
161.0\end{array}$ & $\begin{array}{r}3.5 \\
3.9 \\
3.3 \\
4.1 \\
17.2 \\
13.3 \\
6.3 \\
5.4 \\
4.4 \\
3.5\end{array}$ \\
\hline $\mathrm{H}_{1} \mathrm{SO}_{4}$ & $\begin{array}{l}5(1 n) \\
15(3 n) \\
15 \\
25(5 n) \\
25 \\
15 \\
15 \\
25(5 n) \\
25\end{array}$ & $\begin{array}{l}80 \\
80 \\
80 \\
80 \\
80 \\
60 \\
60 \\
60 \\
60\end{array}$ & $\begin{array}{l}\overline{-} \\
0.05 \\
\overline{0.05} \\
\overline{0.05} \\
\overline{0.05}\end{array}$ & $\begin{array}{l}2,490 \\
7,740 \\
7,050 \\
5,810 \\
4,440 \\
2,600 \\
2,130 \\
4,260 \\
2,620\end{array}$ & $\begin{array}{l}3.0 \\
3.0 \\
3.4 \\
3.4 \\
4.1 \\
3.8 \\
3.5 \\
3.0 \\
4.0\end{array}$ & $\begin{array}{l}-230 \\
-210 \\
-200 \\
-185 \\
-177 \\
-192 \\
-181 \\
-191 \\
-180\end{array}$ & $\begin{array}{r}55.6 \\
172.0 \\
157.0 \\
130.0 \\
99.3 \\
58.0 \\
47.5 \\
95.0 \\
58.6\end{array}$ & $\begin{array}{l}18.7 \\
12.6 \\
18.1 \\
13.7 \\
21.1 \\
14.6 \\
16.8 \\
22.3 \\
14.9\end{array}$ \\
\hline
\end{tabular}

す。この表の第 7 項は短絡電位 $\left(E_{M}\right)$ であり,第 5 項はそ の条件下における $\mathrm{FeO}$ 極の溶解電流，第 8 項はそれを 溶解速度に直したものである。また第 6 項は電池の短絡 電流 $\left(I_{\text {e }}\right)$ の溶解電流に対する比率を \%で表わしたも ので, これは前述のように $\mathrm{FeO}$ 中に含まれる $\mathrm{Fe}^{3+}$ イ オンの割合に相当する。理論値 3\% からの ‘ずれ’ は実

*8一応このような表現をとったけれども，実際には (13) および (14) 式のように, 酸化物の電子電流 $\left(I_{6}\right)$ と溶解電流 $\left(I_{\mathrm{Fe}}{ }^{2+}\right)$ とは相 補的なるのであって切り離して考えることはできない。すなわち尔 宿暴度 ( $\mathrm{Fe}^{3+}$ 含量) が一定であれは, $I_{\mathrm{Fe}}^{2+}$ の増大によって

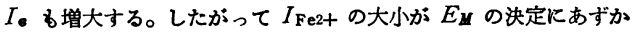
るといってもよい。
験誤差である。第 9 項は酸洗損失 (pickling loss) と呼 ぶベきものであって, 酸化物の溶解電流に対する $\mathrm{Fe}$ (地 鉄のモデル）の溶解電流の比率を意味している。この量 は実際の酸洗の効率を予想するために重要である。すな わち, 酸洗損失はできるだけ小さなことが望ましい。し かし， $\mathrm{FeO}$ 中に $\mathrm{Fe}^{3+}$ が含まれていると，その溶解には 常に ${ }_{1} \mathrm{Fe}^{3+}+e \longrightarrow{ }_{2} \mathrm{Fe}^{2+}$ なる還元溶解反応が伴い, しか もこれが進行するためには相手極 Fe において同一の速 度（すなわち $I_{e}$ ）で $\mathrm{Fe} \longrightarrow \mathrm{Fe}^{2+}+2 e$ なる反応が起こ らなければならない。要するに, $\mathrm{Fe}$ の水素発生型自己 溶解反応が全く起こらない理想的な場合でも酸 洗 損 失 P.L. の值は $3 \%$ 程度になるはずであって，これはいわ ば “避けられない酸洗損失’である。

表 2 の結果をみると，5～25\% $\mathrm{H}_{2} \mathrm{SO}_{4}$ 溶液 $\left(60^{\circ} \sim 80\right.$ ${ }^{\circ}$ C) では P. L. 值はかなり大きいけれどもほぼ一定であ り，それに対して $\mathrm{FeO}$ の溶解電流は高温ほど大きいの で, 高温度で酸洗するのが有利である。また $\mathrm{HCl}$ 溶液 の場合には, $12 \sim 18 \%, 20^{\circ} \sim 47^{\circ} \mathrm{C}$ の範囲で $\mathrm{FeO}$ の溶 解速度も十分大きく, しかも $\mathrm{H}_{2} \mathrm{SO}_{4}$ 溶液の場合よりも P. L. 值が小さいので好都合である。しかし濃度を $24 \%$ $\left(47^{\circ} \mathrm{C}\right)$ に上げると P. L. はかなり増大する。ここで使 用しているインヒビターは与えられた濃度において P. L. 值をほとえど低下させることなく,逆に溶解電流を低 下させているので，ほとえどインヒビターとしての役割 りを果していない。インヒビターとしては Fe の自己腐 食をおさえるとともに, 酸化物スケールの溶解速度にあ まり影響を与えないものが望をしいのである。

電気化学的モデルによる Engell 一派の実験的研究 は，主として $\mathrm{FeO}$ にのみ限定されており，しかもあま り系統的なものではないがこの種の研究方法を他種酸化 物にまで拡大し, さらに溶液側の諸条件を変化した際の 影響を詳細に調べれば, 酸洗機構の基本的理解に対しか なり有効であると思う。

\section{8. 結}

\section{言}

以上鉄鋼表面スケールの構造の概略を述べ, 酸洗反応 の電気化学的モデルについて解説を行なった。前者に関 しては著者らの知識の不足から不備の点も多々あるかと 思う。また後者の Engell らの概念電気化学の立場か らはきわめて興味深いものであるが，もちろん酸洗機構 の全般を説明しうるものとは思われない。ただ従来半経 験的に取り扱われていた酸洗工程の中に種々の基礎的な 問題点が存在することを再認識していただき，今後の技 術進展のご参考ともなれば望外の幸いである。

本稿の執筆に当り, 北大工学部応用化学科 岡本剛教 授および同教室の方々, 治金工学科 吉井周雄・田中時 昭両教授の有益なご助言をいただいた。記して謝意を表 します。 


\section{考支 献}

1) L. B. Pfeil: J. Iron Steel Inst., 119, 501 (1929); 123, 237 (1931)

2) H.J. Engell: Arch. Eisenhuttenw., 28, 109 (1957)

3) M. H. Davies, M. T. Simnad \& C. E. Birchenall: J. Metals, 3, 889 (1951)

4) J. Paidassi: Acta. Met., 6, 184 (1958)

5)高木甲子雄：铁と鋼, 50, 637 (1964)

6) E. J. Caule, K. H. Buob \& M. Cohen: J. Electrochem. Soc., 108, 829 (1961)

7) E. A. Gulbransen \& R. Ruka: J. Metals, 188, 1500 (1950)

8) R. Collongues, R. Sifferlen \& G. Chaudron: Rev. Mét., 50, 727 (1953) [文献 (14) 参照]

9) W. A. Fischer, A. Hoffmann \& R. Shimada: Arch. Eisenhuittenw., 27, 521 (1956)

10) W. A. Fischer \& A. Hoffman: ibid, 29, 107 (1958)

11) E. A. Gulbransen \& R. Ruka: Ind. Eng. Chem., 43, 697 (1951)

12) D. E. Davies, U. R. Evans \& J. N. Agar: Proc. Roy. Soc., A 225, 443 (1954)

13) E. J. Caule \& M. Cohen: J. Electrochem. Soc., 108, 843 (1961)

14) S. Garber: J. Iron Steel Inst., 190, 153 (1959)
15) F. Wever \& H. J. Engell: Arch. Eisenhüttenw., 27, 475 (1956)

16) H. J. Engell \& F. K. Peters: ibid, 28, 567 (1957)

17) A. B. Winterbottom \& J. P. Reed: J. Iron Steel Inst., 126, 159 (1932)

18) E. D. Martin: AISI Yearbook (1948) p. $602 \sim 654$

19) C. B. Murton \& M. F. Hawks: Iron Age, 160, 46 (1947)

20) H. G. Oswin \& M. Cohen: J. Electrochem. Soc., 104, 9 (1957)

21) M. J. Pryor \& U. R. Evans: J. Chem. Soc., 1950, 1259, 1266,1274

22) T. P. Hoar: Iron Steel Ind., 10, 340 (1937)

23) U. R. Evans: "The Corrosion and Oxidation of Metals", Edward Arnold Publishers Ltd., London (1960) p. 406

24）柳 文修, 渡辺達婎, 西村 建：鉄と銅 43, 988 (1957)

25) W. Lueg, W. Dahl \& H.J. Engell: Stahl u. Eisen, 76, 1678 (1956)

26) C. Wagner: Z. Elektrochem., 44, 507 (1938)

27) H. J. Engell: Z. Physik. Chem., N. F. 7, 158 (1956)

28) M. Nagayama \& M. Cohen: J. Electrochem. Soc., 109, 781 (1962); 110, 670 (1963)

29) H. J. Engell: Z. Elektrochem., 60, 905 (1956)

\section{NACE 腐食用語集 $(7)$}

\section{Pitting}

Localized corrosion taking the form of cavities at the surface.

\section{Pitting Factor}

The depth of the deepest pit resulting from corrosion divided by the average penetration as calculated from weight loss.

\section{Polarization}

The displacement of electrode potential resulting from the effects of current flow, measured with respect to either equilibrium (reversible) or steady state potentials.

\section{Reduction}

Gain of electrons by a constituent of a chemical reaction.

\section{Rust}

Corrosion product consisting primarily of hydrated iron oxide. A term properly applied only to iron and ferrous alloys.

\section{Sacrificial Protection}

Reduction or prevention of corrosion of a metal in an environment acting as an electrolyte by coupling it to another metal which is electrochemically more active in that particular elect. rolyte.

\section{Scaling}

1. The formation at high temperature of thick corrosion product layer(s) on a metal surface.

2. The deposition of water-insoluble constituents on a metal surface (as on the interior of water boilers).

\section{Season Cracking}

Cracking resulting from the combined effect of corrosion and internal stress. A term usually applied to stress corrosion cracking of brass.

\section{Slushing Compound}

A non-drying oil, grease, or similar organic compound which, when coated over a metal, affords at least temporary protection against corrosion.

\section{Spalling}

The chipping, fragmenting, or separation of a surface or surface coating.

\section{Standard Potential (Standard Electrode Potential)}

The reversible potential for an electrode process when all products and reactants are at unit activity on a scale in which the potential for the standard hydrogen half-cell is zero.

Corrosion, 20, No. 8, $267 \mathrm{t} \sim 68 \mathrm{t}$ (1964) Aug. 